\title{
E-MRS Charts Course for 1986
}

The Materials Research Society is extremely pleased to be able to present in this issue of the MRS BULLETIN information on some important recent developments in the organization and activities of the European-Materials Research Society (EMRS). E-MRS President Paul Siffert has announced that E-MRS has recently been registered in France, giving the organization official status as a scientific society. Members of E-MRS's first Executive Committee are listed in this issue, along with an unofficial English translation of the official French E-MRS Statutes. Also in this issue, the chairmen of the three symposia which comprised E-MRS's 1985 Fall Meeting

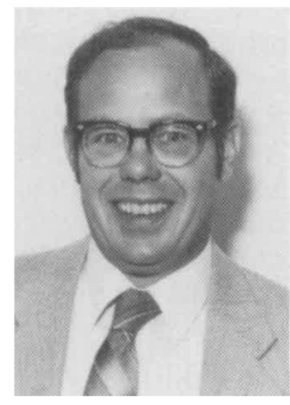

Gordon E. Pike, MRS President

provide reports on this highly successful event.

And the momentum continues. In June, E-MRS holds its next scientific meeting which encompasses scientific advancements in materials for telecommunications, laser processing and diagnostics, computer simulation of casting and solidification processes, and dielectric layers in semiconductors. And June 30-July 4, E-MRS will hold its first Summer School on current problems of semiconductor surfaces and interfaces

Congratulations to E-MRS for its growing list of achievements. We look forward to continued cooperation between E-MRS and the Materials Research Society to further the interdisciplinary approach to materials research and the worldwide exchange of scientific knowledge.

\section{E-MRS Established as Official Scientific Society}

The January/February issue of the MRS BULLETIN announced that the European Materials Research Society (E-MRS) had drafted a set of statutes which, upon approval by the European materials science community, would be registered with the French Court. The Statutes of the European Materials Research Society have recently been approved and officially registered, making E-MRS a recognized scientific society by all the countries of Europe.

The Society's governing Executive Committee was also then established for the first year to oversee the operations of EMRS. The Executive Committee consists of:

\section{President: P. Siffert}

Vice Presidents: J.P. Massue (representative of the Parliamentary Assembly and the
Division of the University Education and Research of the Council of Europe)

J.G. Wurm (representative of the European Communities) V.T. Nguyen (in charge of relationship with the United States)

Representatives:

D. Bauerle, Austria

L. Laude, Belgium

J. Bottiger, Denmark

S. Kalbitzer, Federal Republic of Germany

M. Rodot, France

D. Weaire, Ireland

G. Bentini, Italy

P.F. Bongers, The Netherlands

J.C. Soares, Portugal

F. Agullo-Lopez, Spain

H. Fredriksson, Sweden

M. von Allmen, Switzerland

\section{J.B. Speight, United Kingdom}

Secretary: E.F. Krimmel

Treasurer: P. Pinard

Assessors: J. Th. de Hosson

P. Glasow

M. Cardona

E. Rimini

B. Stritzker

D.G. Altenpohl

F. Buchy

A.G. Cullis

E. Sirtl

The text of the Statutes of the European Materials Research Society has been translated from the official French and appears unabridged in this issue of the BULLETIN.

\section{Proceedings of the 1984 E-MRS Meeting}

Poly-Micro-Crystalline and Amorphous Semiconductors

Amorphous Metals and Non-equilibrium Processing

Induced Defects in Insulators
MRS Members: $\$ 52.00$

MRS Members: $\$ 40.00$

MRS Members: $\$ 34.00$ 